\title{
An Overview of Enhanced Oil Recovery Methods in Fractured Carbonated Reservoirs
}

\author{
Afshin Davarpanah* \\ Department of Petroleum Engineering, Islamic Azad University, Iran
}

Submission: March 20, 2017; Published: April 19, 2017

*Corresponding author: Afshin Davarpanah, Department of Petroleum Engineering, Science and Research Branch, Islamic Azad University, Tehran, Iran, Email: afshindpe@gmail.com

Abstract

In some cases that the fluid (oil) enter in the bottom of the well and the fluid pressure in the bottom of the well is not capable to bring them to wellhead, other techniques such as gas lift (gas is injected from the surface into the well and this gas with well oil creates mixed miscibility that the density is less than primary oil density and can be transmitted oil to wellhead with that bottom pressure) or down-hole pumps (the oil is pumped from the bottom to wellhead by this device) is used. But, this technique is not mentioned as one of EOR methods.

\section{Introduction}

When a reservoir was being drilled, firstly it was produced by the natural mechanisms. Natural mechanisms provided the substantial energy to push the fluid mainly included oil and gas to the surface $[1,2]$. Oil expansion is a very important part among those mechanisms if without availability of other artificial introduced energy. The rock and fluids expand due to their individual compressibility $[3,4]$. Since the fluid was expanded and the matrix pore volume was imbibed by the surrounding fluid, the reservoir pressure was plunged. As a result, the crude oil and water will be forced out of the pore space to the wellbore $[5,6]$.

Primary recovery or natural production is applied for oil extraction under natural driving mechanisms in reservoir without the use of external energy such as gas and water. As it mentioned before, a reservoir has economic production for a short period. In the natural production of reservoir, oil drift is run due to certain mechanisms; we will express them as below $[7,8]$.
A. Rock and Fluid expansion|
B. Solution Gas Drive
C. Gas Cap Drive
D. Water table Drive
E. "Gravity Drive
F. Enhanced Oil Recovery

Certainly, enhanced oil recovery (EOR) methods are named as techniques that the fluid inject into the reservoir and this process energize the fluid so, the aim of these methods, is reducing amount of waste oil reservoir. These methods are divided into two categories:
A. Secondary Recovery
B. Tertiary Recovery

\section{Conclusion}

The importance of oil reservoirs injection is being classified as below:

Gas injection in oil fields is one of the top priorities of Oil Companies in context of quality target. This major is important for several reasons:

A. The necessary of hydrocarbon resources protection for posterity rights.

B. The necessary of national wealth preservation providing long-term investment in oil section and other sectors of the economy and the strength of countries economic infrastructure.

C. Dependence of countries economy on revenues from crude oil exports.

\section{References}

1. Benham AL, Dowden WE, Kunzman WJ (1960) Miscible Fluid Disolacement-Prediction of Miscibility. AIME 219: 229-237.

2. Hutchinsun CA, Braun PH (1961) Phase Relations of Miscible Disolacement IN Oil Recovery. AICHE J 7(1): 64-72.

3. Latil M (1980) Enhance Oil Recovery Institute Francis du Petrole Publications 
4. Metcalfe RS, Yarborough L (1979) The Effect of Phase Equilibria on the $\mathrm{CO}_{2}$ Disolacement Mechanism. SPEJ 19(4): 242-252.

5. Danesh A (2000) PVT and Phase Behavior Of Petroleum Reservoir Fluids. Elsevier 47: 400.

6. Kou ss (1985) Prediction of Miscibility Pressure Correlation SPE 14152, Proc Of 60th SPE Ann Conf.
This work is licensed under Creative

Commons Attribution 4.0 Licens

DOI: $10.19080 /$ RAPSCI.2018.01.555552
7. Simon R, Graue DJ (1965) Generalized Correlation for Predicting Solubility, Swelling and Viscous Behavior of $\mathrm{CO}_{2}$-Crude Oil System. JPT 17(1): 102-106.

8. Crawford HR, Neill GH, Bocy BJ, Crawford PB (1963) Carbon Dioxide-A Multi-Purpose Additive for Effective Well Stimulation. JPT 15(3): 137242.

\section{Your next submission with Juniper Publishers} will reach you the below assets

- Quality Editorial service

- Swift Peer Review

- Reprints availability

- E-prints Service

- Manuscript Podcast for convenient understanding

- Global attainment for your research

- Manuscript accessibility in different formats

( Pdf, E-pub, Full Text, Audio)

- Unceasing customer service

Track the below URL for one-step submission

https://juniperpublishers.com/online-submission.php 